\title{
VARIASI GENOTIP LOKAL TANAMAN CENTRO (Centrosema pubescens) SEBAGAI PAKAN TERNAK
}

\author{
Genotypic Variation of Centro Indigenous (Centrosema pubescens) plants as \\ animal feed
}

\author{
Hanief Eko Sulistyo $^{1)}$, Siti Nurul Kamaliyah ${ }^{1)}$, Imam Tatang Mustofa ${ }^{2)}$ \\ 1) Dosen Nutrisi dan Makanan Ternak Fakultas Peternakan, Universitas Brawijaya Jalan Veteran, \\ Ketawanggede, Kec. Lowokwaru, Kota Malang, Jawa Timur, Indonesia 65145 \\ 2) Mahasiswa Teknologi Hasil Ternak Fakultas Peternakan, Universitas Brawijaya Jalan Veteran, \\ Ketawanggede, Kec. Lowokwaru, Kota Malang, Jawa Timur, Indonesia 65145 \\ Email: hestyo97@yahoo.co.id
}

Diterima Pasca Revisi: 25 Februari 2021

Layak Diterbitkan: 1 Maret 2021

\begin{abstract}
ABSTRAK
Tujuan penelitian ini untuk memberikan informasi keragaman karakter kuantitatif produksi hijauan pakan ternak pada genotip lokal Centro (Centrosema pubescens) sebagai materi seleksi perbaikan genetik tanaman. Materi yang digunakan adalah biji tanaman Centro yang didapat dari Sragen, Kebumen, Bogor, Probolinggo, Malang 1 dan Malang 2. Metode penelitian menggunakan perlakuan biji tanaman Centro yang kemudian ditanam dalam satu petakan. Parameter yang diukur adalah Panjang batang, jumlah daun dan berat hijaun pada umur 80 hari. Analisis data yang digunakan yaitu nilai ragam yang dibandingkan dengan nilai standar devisiasi sehingga dapat menentukan luas dan sempitnya nilai keragaman. Hasil studi menunjukkan keragaman genotip Malang 1, Probolinggo, Sragen, Bogor dan Kebumen termasuk dalam kategori keragaman luas, sedangkan genotip Malang 2 termasuk dalam keragaman sempit pada karakter hijauan. Kesimpulan dari penelitian ini yaitu genotip pada Centrosema pubescens dapat dijadikan materi seleksi untuk pemuliaan hijauan pakan ternak. Pada karakter jumlah daun dan Panjang batang dapat dilakukan seleksi dari biji tanmaan yang didapat di Kebumen, sedangkan pada Panjang batang dari Bogor.
\end{abstract}

Keywords: Keragaman, jumlah daun, panjang batang, berat hijauan centrosema pubescens

How to Cite:

Sulistyo, h. E., Kamilayah, S.N., \& Mustofa, I.T. (2021). Variasi Genotip Lokal Tanaman Centro (Centrosema Pubescens) Sebagai Pakan Ternak. Jurnal Nutrisi Ternak Tropis 4 (1) 32-39

\author{
*Corresponding author: \\ Hanief Eko Sulistyo \\ Email: hestyo97@yahoo.co.id \\ Fakultas Peternakan, Universitas Brawijaya Jalan \\ Veteran, Ketawanggede, Kec. Lowokwaru, Kota \\ Malang, Jawa Timur, Indonesia 65145
}




\section{ABSTRACT}

The purpose of this study was to provide information on the quantitative characters of forage production in local genotypes of Centro (Centrosema pubescens) as selection material for plant genetic improvement. The material used was the Centro plant seeds obtained from Sragen, Kebumen, Bogor, Probolinggo, Malang1, and Malang 2. The research method used the Centro plant seed treatment, which was then planted in one plot. Parameters measured were stem length, number of leaves, and forage weight at 80 days of age. The data analysis used was the variance value that was compared with the standard deviation value so that it could determine the extent and narrowness of the variability value. The results showed that the genotype diversity of Malang 1, Probolinggo, Sragen, Bogor, and Kebumen was included in the broad diversity category, while the genotype of Malang 2 was included in the narrow diversity of forage characters. This study concludes that the genotypes in Centrosema pubescens can be used as selection material for forage breeding. The character number of leaves and stem length can be selected from the seeds obtained in Kebumen, during the length of the stem from Bogor.

Keywords: Variability, number of leaves, stem length, weight offorage, Centrosema pubescens

\section{PENDAHULUAN}

Populasi ternak ruminansia (Sapi Potong, Sapi Perah, Kerbau, Kambing dan Domba) di indonesia terus mengalami perkembangan dari 41.181.549 ekor pada tahun 2009 menjadi 55.591.308 ekor pada tahun 2019 (BPS., 2020). Penentuan keberhasilan usaha peternakan sangat dipengaruhi oleh kuantita, kualitas dan ketersediaan pakan karena biaya produksi dalam usaha peternakan didominasi oleh pakan (Purbajanti, 2013). Populasi ternak ruminansia yang semakin meningkat menjadi penting untuk diantisipasi dengan upaya mendasar dalam peningkatan produktivitas dan kualitas hijauan pakan ternak melalui program pemuliaan (breeding) guna perbaikan genetik tanaman

Indonesia memiliki dua musim yaitu musim hujan dan musim kemarauPergantian musim hujan dengan musim kemarau, menjadikan fluktuasi produksi hijauan bergeser melimpah ketika musim hujan tetapi terjadi kekurangan (defisit) saat musim kemarau. Penyediaan pakan hijauan saat musim kemarau dengan memanfaatkan limbah pertanian untuk pakan basal ternak ruminansia sebagai pengganti hijauan konvensional, menjadi pilihan sulit yang harus ditempuh.
Suplementasi hijauan legum yang berprotein tinggi dapat mengatasi masalah dalam peningkatan kualitas pakan sekaligus meningkatkan intake (konsumsi) ketika limbah pertanian berkualitas rendah diberikan kepada ternak.

Beberapa tanaman legum tropik yang bersifat perennial (hidup lebih dari satu tahun) berpotensi menjadi alternatif dalam pengadaan hijauan legum pakan ternak saat musim kemarau, salah satu tanaman legume tersebut adalah legum Centro (Centrosema pubescens). Tanaman Centro (Centrosema puberscens) menurut Nworgu dan Fasogbon (2007) mempunyai kandungan protein cukup yaitu sekitar $22.45 \%$, dengan produktivitas mencapai 20 ton/ha/th, bahan kering antara 3-7,5 ton/hektar dan gizinya terdiri atas: abu 8,8\%; EE 3,6\%; SK 31,2\%; BETN 34,4\%; PK 22,0\%; dan TDN 60,7\%.

Tanaman Centro selain sebagai pakan hijauan ternak banyak dipakai sebagai cover crop, centro di Malaysia banyak digunakan sebagai pencegah erosi dan penutup tanah, sedangkan di Indonesia digunakan untuk menekan pertumbuhan alang-alang. Pemanfaatannya sebagai pakan ternak, tanaman centro biasanya ditanam secara campuran dengan tanaman rumput. Hal ini karena sebagai tanaman legum, centro juga dapat menyuplai unsur hara ke dalam tanah 
terutama nitrogen sehingga selalu tersedia dan dapat dipergunakan oleh tanaman lain (Sutedi, 2005).

Tanaman centro (Centrosema pubescens) tumbuh menyebar dan beradaptasi dengan baik di berbagai wilayah tropis maupun sub tropis. Faktor lingkungan tumbuh masing-masing genotip mengakibatkan terjadi seleksi alam maupun mutasi dari generasi ke generasi sehingga populasi terbentuk menjadi berbagai genotip lokal yang mengarah pada homosigositas. Sebagai suatu populasi di alam, genotip lokal merupakan plasma nutfah tanaman centro atau sumberdaya genetik yang menyimpan potensi sumber keragaman pada berbagai karakter kuantitatif sehingga berguna dalam rangka upaya pemuliaan tanaman. Untuk perbaikan genetik pada karakter-karakter yang diinginkan, maka dibutuhkan materi seleksi, antara lain plasma nutfah yang telah tersedia di lingkungan yaitu pada genotip lokal yang mempunyai keragaman tinggi.

Pada tanaman menyerbuk sendiri seperti Centrosema pubescens, keunggulan untuk suatu karakter kuantitatif apabila populasi terdiri dari tanaman galur murni yang individu anggotanya memiliki genotipe seragam karena homosigot untuk (hampir) semua lokus, ketika berulangulang terjadi penyerbukan sendiri dalam proses penggaluran pada karakter kuantitatif tersebut. Penelitian ini menelaah potensi beberapa populasi genotip lokal tanaman Centrosema pubescens dalam pemanfaatannya sebagai hijauan pakan ternak, pada keragaman karakter kuantitatif produksi hijauan yang ditentukan berdasarkan kontinyuitas perbedaan antar individu genotip lokal, antara lain untuk karakter kuantitatif panjang batang, jumlah daun dan berat hijauan.

\section{MATERI DAN METODE}

Penelitian dilaksanakan di di CV Agriranch, Jl. Raya Tawangargo no 100, Leban, Tawangargo, Karang Ploso, Malang.Ketinggian tempat $\pm 600 \mathrm{~m}$ diatas permukaan laut dengan curah hujan rata-rata $1.890 \mathrm{~mm} /$ tahun. Waktu pelaksanaan penelitian mulai bulan Februari sampai April 2020.

\section{Materi}

Materi penelitian yang digunakan adalah tanaman Centrosema pubescens yang terdiri dari 6 populasi genotip lokal berasal dari 6 daerah, meliputi Sragen, Kebumen, Bogor, Probolinggo, Malang (1) dan Malang (2). Pemanenan dilakukan pada saat tanaman centro berumur 80 hari setelah tanam (hst).

\section{Metode}

Metode penelitian menggunakan cara percobaan dengan bentuk Petak Tunggal Termodifikasi. Sejumlah 6 genotip lokal tanaman Centro, masing-masing genotip lokal ditanam sebanyak 4 gulud, dan masing-masing gulud ditempatkan dalam plot secara berkelompok dengan semua genotip lokal yang lain sebanyak 4 plot, sehingga jumlah total guludan sebanyak 42 gulud.

\section{Prosedur Penelitian}

Sebanyak 6 genotip lokal yaitu tanaman centro dari Sragen, Kebumen, Bogor, Probolinggo, Malang 1 dan Malang 2, ditanam dalam1 unit lahan percobaan, dengan jarak tanam 15 X $50 \mathrm{~cm}$, yaitu jarak dalam baris (gulud) $15 \mathrm{~cm}$ dan jarak antarbaris (antar-gulud) $50 \mathrm{~cm}$, sehingga jumlah total adalah 600 individu. Benih ditanam secara tugal sebanyak 1-3 biji per lubang dengan kedalaman 2-3 cm dan disisakan 1 tanaman apabila tumbuh lebih dari satu tanaman. Penyulaman dilakukan pada saat 14 hst dengan tanaman cadangan yang berumur sama

\section{Pengamatan}

Pengamatan dilakukan terhadap tiap individu tanaman centro (Centrosema pubescens) anggota populasi dari masingmasing genotip lokal yang meliputi genotip lokal Sragen, Kebumen, Bogor, Probolinggo, Malang (1) dan Malang (2). Sedangkan parameter yang diamati pada penelitian ini adalah beberapa karakter kuantitatif produksi hijauan meliputi:

1. Jumlah daun tiap tanaman (helai/tnm) 
2. Panjang batang tiap tanaman $(\mathrm{cm} / \mathrm{tnm})$

3. Berat hijauan tiap tanaman (gram/tnm)

\section{Analisis data}

Data yang diperoleh dari 3 (tiga) karakter kuantitatif produksi hijauan tanaman centro (Centrosema pubescens), dilakukan analisis ragam dan standar deviasinya dengan bantuan program komputer Microsoft excel dan dibuat permodelan kuatitatif (Adli dan Sjofjan, 2020). Luas atau sempitnya keragaman ditentukan dengan membandingkan nilai ragam dengan standar deviasinya $(\sigma)$ sesuai ketentuan dari Anderson dan Bancroft (1952) yang dikutip oleh Khomaeni dan Bambang (2011). Rumus yang digunakan untuk mengukur ragam menurut Nurgiariningsih A (2017) adalah sebagai berikut:

$$
\sigma^{2}=\frac{\left(x_{1}-\bar{x}\right)^{2}+\left(x_{2}-\bar{x}\right)^{2}+\cdots+\left(x_{n}-\bar{x}\right)^{2}}{n-1}
$$

Rumus untuk mengukur standart deviasi adalah sebagai berikut:

$$
\sigma=\sqrt{\sigma^{2}} \text { atau } s=\sqrt{\sigma^{2}}
$$

Keterangan:

$\begin{array}{ll}x_{1}, x_{2}, x_{n} & =\text { ukuran masing-masing individu dalam populasi } \\ \bar{X} & =\text { rata-rata populasi, } \\ \mathrm{n} & =\text { jumlah individu, } \\ \sigma^{2} & =\text { ragam, } \\ \sigma \text { atau } s & =\text { standart deviasi, }\end{array}$

\section{HASIL DAN PEMBAHASAN}

\section{Produksi Hijauan Centrosema pubescens}

Tanaman centro (Centrosema pubescens) termasuk dalam tanaman legum yang mudah berbunga, berbiji serta dapat dipakai sebagai tanaman campuran dengan berbagai jenis tanaman rumput maupun sebagai tanaman sisipan pada padang penggembalaan. Tanaman centro banyak dimanfaatkan sebagai hijauan legum pakan ternak dan tanaman legum penutup tanah yang dikenal mampu memperbaiki kondisi tanah, sifat kimia tanah sepertibahan organik. Tanaman centro juga dapat meningkatkan kualitas hijauan terutama pada kandungan protein (Sutedi,2005). Ibrahim (1995) menambahkan bahwa tanaman Centrosema pubescens mampu hidup pada keadaan musim kering sampai 6 bulan kering dan tahan terhadap kondisi lahan yang tergenang air. Hasil hijauan basah Centrosema sebesar 20 ton/ha/th sedangkan, bahan kering tiap hektar Centro cukup tinggi, yaitu antara 3-7,5 ton/hektar.
Komposisi zat gizi daun Centro (dasar bahan kering) terdiri atas: abu 8,8\%; EE 3,6\%; SK 31,2\%; BETN 34,4\%; PK 22,0\%; dan TDN 60,7\% (Susetyo, 2001), (Harjadi, 2000). Komposisi dari daun centro di analisis prokisimat untuk mengetahui kandungan proteinnya (Sjofjan et al., 2020). Hasil penelitian yang dilakukan menunjukkan bahwa pada 6populasi genotip lokal, tidak semua benih yang ditanam dapat tumbuh sampai dewasa karena beberapa masalah antara lainbenihtidak tumbuh, tumbuh tidak normal maupun kematian dini. Hal ini disebabkan oleh fenomena seleksi alam terhadap populasi masing-masing genotip lokal ketika ditumbuhkan di lingkungan baru yang tidak sepenuhnya sama dengan habitat aslinya. Ketidakmampuan tumbuh untuk menyelesaikan siklus hidup dari pertumbuhan vegetative sampai berkembangbiak dalam fase generatif pada lingkungan yang baru yaitu kondisi agroklimat dilokasi penelitianditandai dengan kegagalan tumbuh yang dapat 
dikatagorikan menjadi 2 kelompok yaitu: 1). pada genotip lokal Malang1, Malang2, Sragen dan Bogor tergolong gagal-tumbuh rendah (0-15\%), dan 2) untuk genotip lokal Probolinggo dan Kebumen tergolonggagaltumbuhsedang (31-35 \%). Sedangkan individu-individu anggota populasi 6 genotip lokal yang mampu beradaptasi dapat tumbuh sampai umur panen (80 hst) dan menunjukkan kemampuan berproduksi (fenotip) sesuai potensi genetiknya dalam merespon kondisi lingkungan yang sama.

Tabel 1. Nilai Rerata dan Kisaran beberapa parameter karakter kuantitatif produksi hijauan pada 6 genotip lokal tanaman centro umur 80 hst

\begin{tabular}{cccccccc}
\hline $\begin{array}{c}\text { Genotip } \\
\text { Lokal }\end{array}$ & $\begin{array}{c}\text { Gagal } \\
\text { Tumbuh }(\%)\end{array}$ & \multicolumn{2}{c}{$\begin{array}{c}\text { Panjang Batang } \\
(\mathrm{cm} / \text { tnm) }\end{array}$} & \multicolumn{2}{c}{$\begin{array}{c}\text { Jumlah Daun } \\
\text { (helai/tnm) }\end{array}$} & \multicolumn{2}{c}{$\begin{array}{c}\text { Berat Hijauan } \\
(\mathrm{gr} / \mathrm{tnm})\end{array}$} \\
\cline { 3 - 8 } & & Kisaran & Rerata & Kisaran & Rerata & Kisaran & Rerata \\
\hline Malang 1 & 10 & $9-141$ & 31.33 & $10-51$ & 24.74 & $1.29-13.20$ & 3.78 \\
Malang 2 & 14 & $8-152$ & 28.40 & $9-59$ & 22.36 & $1.21-13.36$ & 3.06 \\
Probolinggo & 35 & $8-122$ & 31.90 & $12-60$ & 22.97 & $1.66-11.27$ & 3.50 \\
Sragen & 15 & $4-163$ & 32.14 & $12-69$ & 24.89 & $1.30-11.95$ & 3.84 \\
Bogor & 0 & $9-177$ & 41.56 & $12-89$ & 27.67 & $1.24-14.91$ & 4.27 \\
Kebumen & 31 & $12-182$ & 40.38 & $15-112$ & 32.92 & $1.41-19.30$ & 4.42 \\
\hline
\end{tabular}

Pada beberapa karakter produksi hijauan menunjukkan nilai rata-rata produksipanjang batangpada 6 genotip lokal dapat dikatagorikan menjadi 2 kelompok yaitu: 1). genotip lokal Malang1, Malang2, Probolinggo dan Sragen, tergolong sedang $(28-32 \mathrm{~cm} / \mathrm{tnm})$ dan 2$)$. Genotip lokal Bogor dan Kebumen tergolong tinggi $(40-42 \mathrm{~cm} / \mathrm{tnm})$. Untuk nilai rata-rata produksijumlah daun pada 6 genotip lokal dapat dikatagorikan menjadi 2 kelompok yaitu: 1). genotip lokal Malang1, Malang2, Probolinggo dan Sragen, tergolong sedang (22-25 helai/tnm), dan 2). Genotip lokal Bogor dan Kebumen tergolong tinggi (27-33helai /tnm) untuk nilai rata-rata produksiberat hijauanpada 6 genotip lokal dapat dikatagorikan menjadi 3 kelompok yaitu: 1). genotip Malang 2 tergolong rendah (3.06 gr/tnm), 2).genotip lokal Malang1dan Probolinggo tergolong sedang (3.5 - $3.9 \mathrm{gr} / \mathrm{tnm})$, dan 3)genotip lokal Sragen, Bogor dan Kebumen tergolong tinggi (3.9-4.5 gr/tnm)(Tabel 1.), Hal ini menunjukkan bahwa terdapat perbedaan kemampuan beradaptasi masingmasing individu tanaman centro yang berasal dari populasi genotip lokaldari berbagai daerah. Menurut Widodo (1984) bahwa natural selection merupakan hukum alam dan sebagai hasil evaluasi secara alamiah. Tanaman yang kuat menghadapi keadaan alam akan tetap hidup, sebaliknya yang tidak kuat akan tersingkir dan punah dibawah kondisi alamiah sebenarnya mutasi-mutasi gen menghasilkan tanamantanaman dengan tingkat kematian yang tinggi sehingga banyak tanaman tersebut musnah.

\section{Keragaman Tanaman Centrosema pubescens}

Keragaman karakter dan keanekaragaman genotip berguna untuk mengetahui pola pengelompokan genotip pada populasi tertentu berdasarkan karakter yang diamati dan dapat dijadikan sebagai dasar kegiatan seleksi (Agustina \& Waluyo, 2017). Luas sempitnya keragaman ditentukan dengan membandingkan nilai ragam dengan standar deviasinya $(\sigma)$ sesuai ketentuan dari Anderson dan Bancroft (1952). Keragaman dinyatakan luas bila nilai ragam/varians lebih besar dari dua kali standar deviasinya $\left(\sigma^{2}>2 \mathrm{Sd} \sigma\right)$, sebaliknya keragaman dinyatakan sempit bila nilai variansnya lebih kecil atau sama dengan dua kali nilai standar deviasinya $(\sigma 2 \leq 2 \mathrm{Sd} \sigma)$ (Khomaeni dan Bambang, 2011). Hasil anilisis keragaman pada 6 genotip lokal tanaman centro didapatkan bahwa 
keragaman fenotip Malang1, Probolinggo, Sragen, Bogor, Kebumen termasuk dalam kategori luas pada karakter panjang batang, jumlah daun, maupun berat hijauan, sedangkan pada genotip Malang2 mempunyai keragaman dalam kategori sempit pada karakter berat hijauan, walaupun pada karakter panjang batang dan jumlah daunnya sendiri termasuk dalam kategori keragaman luas (Tabel. 2).

Tabel 2. Nilai ragam $\left(\sigma^{2}\right)$, standart deviasi $(\sigma)$, Dua kali nilai standar deviasi $(2 \sigma)$, pada beberapa karakter tanaman Centro.

\begin{tabular}{cccccc}
\hline \multirow{3}{*}{ Genotip } & Karakter & $\begin{array}{c}\text { Ragam } \\
\left(\sigma^{2}\right)\end{array}$ & $\begin{array}{c}\text { Std deviasi } \\
(\sigma)\end{array}$ & $\begin{array}{c}\text { 2 Std deviasi } \\
(2 \sigma)\end{array}$ & Keragaman \\
\hline Malang 1 & Panjang Batang & 883.52 & 29.72 & 59.45 & Luas \\
& Jumlah Daun & 220.89 & 14.86 & 29.72 & Luas \\
& Berat Hijauan & 5.53 & 2.35 & 4.70 & Luas \\
Malang 2 & Panjang Batang & 728.55 & 26.99 & 53.98 & Luas \\
& Jumlah Daun & 109.64 & 10.47 & 20.94 & Luas \\
& Berat Hijauan & 3.85 & 1.96 & 3.93 & Sempit \\
Probolinggo & Panjang Batang & 1040.66 & 32.26 & 64.52 & Luas \\
& Jumlah Daun & 133.06 & 11.54 & 23.07 & Luas \\
& Berat Hijauan & 5.64 & 2.37 & 4.75 & Luas \\
& Panjang Batang & 966.26 & 31.08 & 62.17 & Luas \\
& Jumlah Daun & 122.24 & 11.06 & 22.11 & Luas \\
& Berat Hijauan & 6.05 & 2.46 & 4.92 & Luas \\
& Panjang Batang & $1651.86^{*}$ & 40.64 & 81.29 & Luas \\
& Jumlah Daun & 198.30 & 14.08 & 28.16 & Luas \\
& Berat Hijauan & 9.71 & 3.12 & 6.23 & Luas \\
Kebumen & Panjang Batang & 1638.38 & 40.48 & 80.95 & Luas \\
& Jumlah Daun & $433.51^{*}$ & 20.82 & 41.64 & Luas \\
& Berat Hijauan & $11.81^{*}$ & 3.44 & 6.87 & Luas \\
\hline
\end{tabular}

*Nilai ragam tertinggi pada masing-masing karakter

Menurut Budiyanti, (2007) bahwa keragaman genetik yang tinggi mempengaruhi keragaman fenotipik suatu populasi, sehingga terdapat peluang lebih besar dalam melakukan seleksi. Keragaman genetik yang rendah tidak memberi peluang yang besar dalam memilih fenotip yang diinginkan. Keragaman yang sempit menunjukkan bahwa suatu individu dalam populasi tersebut memiliki karakter yang hampir sama sehingga proses seleksi tidak efektif. Tingginya keragaman memberikan peluang yang semakin baik dalam perbaikan karakter yang dikehendaki (Nur A dkk,2013). Jameela dkk (2014) menambahakan bahwa semakin tinggi keragaman genetik yang dimiliki akan semakin besar peluang keberhasilan bagi program pemuliaan tanaman.

Disamping itu, keragaman genetik yang tinggi juga dapat meningkatkan respon seleksi karena respon seleksi berbanding lurus dengan keragaman genetik. Dalam pemanfaatannya sebagai sumber hijauan, dapat dinyatakan bahwa tanaman centro genotip lokal Malang1, Probolinggo, Sragen, Bogor, Kebumen mempunyai peluang untuk dilakukan proses seleksi secara efektif sebagai tanaman yang menghasilkan hijauan pada karakter kuantitatif panjang batang, jumlah daun, dan berat hijauan. Sedangkan pada genotip lokal Malang2 tidak berpotensi untuk dilakukan proses seleksi, karena pada 
karakter berat hijauan menunjukkan keragaman yang sempit, sehingga individu anggota populasi genotip lokal Malang2 dapat dikatakan seragam atau kurang beragam sehingga tidak efektif untuk dilakukan proses seleksi. Hal ini merupakan indikasi perbedaan peran pada karakterkarakter kuantitatif tersebut. yaitu bahwa karakter kuantitaif berat hijauan merupakan pencerminan dari akumulasi hasil pertumbuhan dan perkembangan tanaman yang didukung oleh proses-proses fisiologis tanaman, sedangkan karakter panjang batang dan jumlah daun untuk memfasilitasi keberlangsungan prosesproses fisiologis seperti daun untuk fotosintesis dan transpirasi maupun prosesproses mobilisasi dalam jaringan pembuluh batang. Berdasarkan analisis produksi hijauandan keragamankarakter panjang batang, jumlah daun, dan berat hijauan dari ke-6genotip tanaman centrodapat dikemukakan bahwa genotip-genotip lokal tanaman centro secara keseluruhan dapat dijadikan materi seleksi pada karakter panjang batang, jumlah daun dan berat hijauan kecuali genotip lokal tanaman centro yang berasal dari Malang2. Tanaman centro yang mempunyai potensi lebih tinggi untuk dilakukan proses seleksi dibanding genotip tanaman centro lainnya adalah genotip lokal yang berasal dari Kebumen dengan produksi hijauan dan nilai ragam paling tinggi pada karakter jumlah daun dan berat hijauan, sedangkan untuk potensi seleksi paling tinggi pada karakter panjang batangadalah genotip yang berasal dari Bogor yang mempunyai jumlah produksi hijauan dan nilai ragam paling tinggi pada karakter tersebut.

\section{KESIMPULAN}

- Kegagalan tumbuh akibat seleksi alam terhadap 6 populasi genotip lokal adalah sebesar 35\%, 31\%, 15\%, 14\%, 10\% dan $0 \%$ masing-masing pada genotip lokal Probolinggo, Kebumen, Sragen, Malang2, Malang1 dan Bogor.

- Keragaman tanaman centro pada 6 genotip lokal Malang1, Probolinggo, Sragen, Bogor, Kebumen termasuk dalam kategori luas pada karakter panjang batang, jumlah daun, maupun berat hijauan, dapat dijadikan sebagai materi seleksi pemuliaan hijauan pakan ternak

- Pada karakter panjang batang diperoleh nilai rataan untuk 6 populasi genotip lokal adalah sebesar $28.40 \mathrm{~cm} / \mathrm{tnm}, 31,33$ $\mathrm{cm} / \mathrm{tnm}, 31,90 \mathrm{~cm} / \mathrm{tnm}, 32,14 \mathrm{~cm} / \mathrm{tnm}$, $40,38 \mathrm{~cm} / \mathrm{tnm}$, dan $41,38 \mathrm{~cm} / \mathrm{tnm}$ masingmasing pada genotip local Malang2, Malang1, Probolinggo, Sragen, Kebumen dan Bogor.

- Pada karakter jumlah daun diperoleh nilai rataan untuk 6 populasi genotip lokal adalah sejumlah 22,36 helai/tnm, 22,97 helai/tnm, 24,74 helai/tnm, 24,89 helai/tnm, 27,67 helai/tnm dan 32,92 helai/tnm masing-masing pada genotip lokal Malang2, Probolinggo, Malang1, Sragen, Bogor dan Kebumen.

- Pada karakter berat hijauan diperoleh nilai rataan untuk 6 populasi genotip lokal adalah sebesar 3,06 g/tnm, 3,50 g/tnm, $3,78 \mathrm{~g} / \mathrm{tnm}, 3,84 \mathrm{~g} / \mathrm{tnm}, 4,27 \mathrm{~g} / \mathrm{tnm}$ dan 4,42 g /tnm masing-masing pada genotip lokal Malang2, Probolinggo, Malang1, Sragen, Bogor dan Kebumen.

\section{DAFTAR PUSTAKA}

Adli, D. N., \& Sjofjan, O. (2020a). MetaAnalisis: Pengaruh substitusi jagung dengan bahan pakal lokal terhadap kualitas karkas daging broiler. Jurnal Ilmu Peternakan Terapan, 3(2), 44-48. https://doi.org/10.25047/jipt.v3i2.1940

Adli, D. N., \& Sjofjan, O. (2020b). Estimasi dan validasi kandungan energi bekatul sebagai pakan unggas dari komposisi kimia pakan. Jurnal Nutrisi Ternak Tropis, 3(2), 90-96. https://doi.org/ 10.21776/ub.jnt.2020.003.02.6

Agustina, N. I., \& Waluyo, B. (2017). Keragaman karakter morfo-agronomi dan keanekaragaman galur- galur cabai besar (Capsicum annuum L.). Jurnal Agro, 4(2), 120-130. https://doi.org/10.15575/1608 
Badan Pusat Statistik Jakarta Pusat. (2020). Populasi Sapi Potong, Sapi Perah, Kerbau, Kambing dan Domba Nasional Menurut Provinsi Tahun 2019. Badan Pusat Statistik.

Budiyanti, T. (2007). Variabilitas dan heritabilitas beberapa karakter buah dari 15 aksesi pepaya generasi F1. Jurnal Penelitian Dan Informasi Pertanian Agrin, 11(2).

Harjadi, S. (2000). Pengantar Agronomi. Gramedia.

Ibrahim. (1988). Feeding Tables For Ruminants In Srilanka (First Edit). Kandy Offset Printers.

Jameela, H., Sugiharto, A. N., \& Soegianto, A. (2014). Keragaman genetik dan heritabilitas karakter komponen hasil pada populasi F2 buncis (Phaseolus vulgaris L.) hasil persilangan varietas introduksi dengan varietas lokal. Jurnal Produksi Tanaman, 2(4), 324329. https://doi.org/10.21176/PRO TAN.V2I4.113

Khomaeni, H. S., \& Bambang, S. (2011). Variabilitas dan seleksi awal populasi tanaman teh hasil persilangan buatan Variability and early selection for tea plant population derived from artificial crossings. Jurnal Penelitian Teh Dan Kina, 14(2), 72-77.

Amin, N., \& Iriany, N. R. (2013).
Variabilitas genetik dan heritabilitas karakter agronomis galur jagung dengan tester $\mathrm{Mr}$ 14. Jurnal Agroteknos, 3(1), 34-40.

Nurgiariningsih, A. (2017). Pengantar Parameter genetik pada ternak. UB Press.

Nworgu, F. C., \& Fasogbon, F. O. (2007). Centrosema (Centrosema pubescens) leaf meal as protein supplement for pullet chicks and growing pullets. International Journal of Poultry Science, 6(4), 255-260. https://doi. org/10.3923/ijps.2007.255.260

Purbajanti, E. (2013). Rumput Dan Legum Sebagai Hijauan Makanan Ternak. Graha Ilmu.

Sjofjan, O., Nur Adli, D., Djunaidi, I., \& Kuncoro, K. (2020). Utilization of biogas liquid waste for starter in the fermentation of rice husk as a potential feed for poultry. ANIMAL PRODUCTION, 22(1), 24-30. https:// doi.org/10.20884/1.jap.2020.22.1.38

Susetyo, S. (1988). Padang Penggembalaan. Fakultas Peternakan IPB.

Sutedi, E. (2005). Agronomi Dan Pemanfaatan Centrosema Pubescens. In Lokakarya Nasional Tanaman Pakan Ternak.

Widodo. (1983). Pemuliaan Tanaman (Sub Proyek). Universitas Gadjah Mada. 